Bangladesh J. Pl. Breed. Genet., 29(2): 11-16, 2016

\title{
GENETIC VARIABILITY AND CHARACTERS ASSOCIATIONS IN RAPESEED (Brassica napus L.)
}

\author{
S. D. Joya ${ }^{1}$, A. K. M. Shamsuddin and U. K. Nath \\ Department of Genetics and Plant Breeding \\ Bangladesh Agricultural University \\ Mymensingh 2202, Bangladesh.
}

\begin{abstract}
Thirty eight rapeseed genotypes were evaluated to estimate the genetic variability and association among the genotypes, following 8 quantitative characters. A considerable amount of genetic variability were found ranges from 1000 seed weight $(11.09 \mathrm{~g})$ to harvest index $(44.00 \%)$ and phenotypic variability for plant height $(13.36 \mathrm{~m})$ to harvest index $(44.14 \%)$. High heritability was found for all characters except 1000 seed weight (67.04g). Minimum genetic advance was observed for 1000 seed weight $(0.63 \mathrm{~g})$ and maximum for plant height $(29.72 \mathrm{~m})$. The lowest genetic advance in percent of mean was found in 1000 seed weight $(18.70 \mathrm{~g})$ and highest in harvest index $(90.35 \%)$. Plant height, raceme length and 1000 seed weight have significant positive association with yield with harvest index. Plant height, raceme length, 1000 seed weight and harvest index have imposed direct positive effect on yield per plant (g). As Plant height, raceme length, 1000 seed weight and harvest index are mainly driven by the additive genes so that selection criteria based on this characters should be effective.
\end{abstract}

Key words: Rapeseeds; genetic variability; heritability; genetic advance.

\section{INTRODUCTION}

Brassica napus L. is second most important oilseed crop in the international oilseed market after soybean and important source of vegetable oil (Verma et al., 2016). Brassica is accounting for over $16 \%$ of the world's edible oil supply (Anonymous, 2015). In Bangladesh, it occupies the 1st position in respect of area and production among the oil crops grown. The genus Brassica has generally been divided into three groups namely rapeseed, mustard and cole. One of the main objectives of any breeding program is to produce high-yielding and better-quality lines for release as cultivars to farmers. The prerequisite to achieve this goal is to find sufficient amount of variability, from which desired lines are to be selected for further exploration to achieve the breeding target. The phenotypic variability is a combined estimation of genetic and environmental causes, of which only the former one is heritable. Seed yield is a complex character that can be determined by several components reflecting positive or negative effects upon this trait, whereas it is important to examine the contribution of each of the various components in order to give more attention to those having the greatest influence on seed yield (Marjanovic- Jeromela et al., 2007). Determination of correlation coefficients is an important statistical procedure to evaluate the association among yield

${ }^{1}$ Biotechnology Division, Bangladesh Rice Research Institute, Gazipur 1701, Bangladesh 
and its contributing traits in breeding programs, as well as to examine direct and indirect contributions to yield (Ali et al., 2003). Again, Path-coefficient technique splits the correlation coefficients into direct and indirect effects via alternative characters or pathways and thus permits a critical examination of components that influence a given correlation, thus path co-efficient analysis can help in formulating an efficient selection strategy (Sabaghnia et al., 2010). Therefore, correlation in combination with the path coefficient analysis quantifies the direct and indirect contribution of one character upon another (Dewey and $\mathrm{Lu}, 1995$ ). The present study was conducted to find out the variability, character association and the direct and indirect effect of different characters on yield per plant which will give an opportunity to select the desired plant types to meet the existing demand.

\section{MATERIALS AND METHODS}

The experiment was conducted with 38 genotypes of rapeseed in the experimental farm of the Department of Genetics and Plant Breeding, Bangladesh Agricultural University, Mymensingh. The experiment was laid out in Randomized Complete Block Design (RCBD) with three replications. Five plants were selected randomly from each plot for collection of data for yield and yield contributing characters viz. plant height, raceme length, siliqua per raceme, siliqua length, seeds per siliqua, 1000 seed weight, harvesting index and yield/plants. The genotypic and phenotypic variances were calculated as per the formula by Burton (1952). Genotypic and phenotypic coefficients of variation were calculated according to the formula given by Falconer (1981). Heritability was calculated according to the formula given by Allard (1960). From the heritability estimates the genetic advance was estimated as per Burton (1953). Genotypic and phenotypic correlation coefficients were estimated using the formula given by Johnson et al. (1955), Miller et al. (1958), Singh and Chaudhury (1985). The direct and indirect effects both at genotypic and phenotypic level were estimated by taking seed yield as dependent variable using path coefficients analysis following to the procedure stated by Singh and Chaudhury (1985) and Dabholkar (1992), which was originally suggested by Dewey and Lu (1959).

\section{RESULTS AND DISCUSSION}

\section{Performance of the genotypes}

Analysis of variance for yield and yield contributing characters of the rapeseed genotypes is presented in Table 1. It appears that there were significant variation among the genotypes for plant height, raceme length, siliqua per raceme, siliqua length, seeds per siliqua, and seed yield per plant, 1000 seed weight. This suggests that there were significant genetic variation among the genotypes for all the characters studied.

Among the yield contributing characters harvest index, yield per plant, seeds per siliqua, siliqua/raceme (exhibited high phenotypic coefficient of variation. The genotype coefficients for plant height, raceme length and siliqua/raceme were close to their phenotypic ones suggesting little influenced of environment on these characters. The variation for other characters also considerable because they were estimated more than $10 \%$ of phenotypic coefficient. The characters suggest that for yield and yield contributing characters showed high heritability when it was estimated. All the characters except 1000 seed weight and siliqua length estimated more than 94\% heritability. The genetic advances of the characters were studied in genetic advance $\%$

mean. The characters, such as, harvest index, seeds per siliqua and siliqua per raceme, 
showed high genetic advance. These characters expressed also high heritability along with their phenotypic coefficient of variation, suggesting selection for these characters would give better response to selection. Therefore, the characters siliqua per raceme, seeds per siliqua, harvest index and seed yield per plant should be included for yield improvement in rapeseed. Khan et al. (2006) studied variation for yield and yield contributing characters in rapeseed and found significant variation for eleven accessions of Brassica napus L. They indicated that a wide range of genetic variation with high phenotypic correlation coefficients and genotypic correlation coefficients for seed yield, siliqua per raceme, seeds per siliqua, siliqua length.

Table 1. Estimates of genetic parameters for various yield and yield contributing characters

\begin{tabular}{l|c|c|c|c|c}
\hline \multicolumn{1}{c}{ Characters } & $\begin{array}{c}\text { Genotypic } \\
\text { variation } \\
(\%)\end{array}$ & $\begin{array}{c}\text { Phenotypic } \\
\text { variation } \\
(\%)\end{array}$ & $\begin{array}{c}\text { Heritability } \\
(\%)\end{array}$ & $\begin{array}{c}\text { Genetic } \\
\text { Advance } \\
(\mathrm{GA})\end{array}$ & $\begin{array}{c}\text { GA in } \\
(\%) \text { of } \\
\text { mean }\end{array}$ \\
\hline Plant height $(\mathrm{cm})$ & 13.32 & 13.36 & 99.28 & 29.72 & 27.33 \\
Raceme length $(\mathrm{cm})$ & 19.27 & 19.44 & 98.32 & 18.27 & 39.37 \\
Siliqua/raceme & 22.45 & 22.83 & 96.72 & 14.13 & 45.49 \\
Siliqua/length (cm) & 15.89 & 17.67 & 80.85 & 1.76 & 29.43 \\
Seed/Siliqua & 24.12 & 24.67 & 95.61 & 9.30 & 48.58 \\
1000 seed weight $(\mathrm{g})$ & 11.09 & 13.54 & 67.04 & 0.63 & 18.70 \\
Harvest index (\%) & 44.00 & 44.14 & 99.36 & 26.19 & 90.35 \\
Yield/plant $(\mathrm{g})$ & 34.11 & 35.39 & 92.93 & 1.56 & 67.74 \\
\hline
\end{tabular}

Association between yield and yield contributing characters of rapeseed

The results of genotypic ( $\mathrm{rg}$ ) and phenotypic ( $\mathrm{rp}$ ) correlation coefficients among seed yield and yield contributing characters in all possible combinations are presented in Table 2. Most of the genotypic correlation coefficient was found to be larger than their corresponding phenotypic correlation coefficients, which indicate inherent relations of these characters.

Table 2. Genotypic (rg) and phenotypic (rp) correlation coefficient among different yield and yield contributing characters

\begin{tabular}{ll|c|c|c|c|c|c|c}
\hline Characters & & $\begin{array}{c}\text { Raceme } \\
\text { length }\end{array}$ & $\begin{array}{c}\text { Siliqua } \\
\text { raceme }\end{array}$ & $\begin{array}{c}\text { Siliqua } \\
\text { length }\end{array}$ & $\begin{array}{c}\text { Seed/ } \\
\text { Siliqua }\end{array}$ & $\begin{array}{c}1000 \\
\text { seed wt }\end{array}$ & $\begin{array}{c}\text { Harvest } \\
\text { index }\end{array}$ & $\begin{array}{c}\text { Yield/ } \\
\text { plant }\end{array}$ \\
\hline Plant height (cm) & $\mathrm{r}_{\mathrm{g}}$ & $0.952^{* *}$ & $0.809^{* *}$ & -0.135 & $-0.597^{* *}$ & -0.055 & $0.854^{* *}$ & $0.484^{* *}$ \\
& $\mathrm{r}_{\mathrm{p}}$ & $0.867^{* *}$ & $0.785^{* *}$ & -0.126 & $-0.588^{* *}$ & -0.037 & $0.848^{* *}$ & $0.468^{* *}$ \\
Raceme length (cm) & $\mathrm{r}_{\mathrm{g}}$ & & $0.986^{* *}$ & $0.886^{* *}$ & $-0.455^{* *}$ & $-0.945^{* *}$ & 0.149 & $0.466^{* *}$ \\
& $\mathrm{r}_{\mathrm{p}}$ & & $0.964^{* *}$ & $0.789^{* *}$ & $-0.443^{* *}$ & $-0.763^{* *}$ & 0.148 & $0.447^{* *}$ \\
Siliqua/raceme & $\mathrm{r}_{\mathrm{g}}$ & & & -0.140 & $-0.869^{* *}$ & $-0.777^{* *}$ & $0.669^{* *}$ & $-0.317^{* *}$ \\
& $\mathrm{r}_{\mathrm{p}}$ & & & -0.137 & $-0.826^{* *}$ & $-0.923^{* *}$ & $0.654^{* *}$ & -0.310 \\
Siliqua length (cm) & $\mathrm{r}_{\mathrm{g}}$ & & & & $0.798^{* *}$ & $-0.980^{* *}$ & -0.191 & $-0.307^{* *}$ \\
& $\mathrm{r}_{\mathrm{p}}$ & & & & $0.783^{* *}$ & $-0.754^{* *}$ & -0.162 & $-0.254^{*}$ \\
Seed/Siliqua & $\mathrm{r}_{\mathrm{g}}$ & & & & & $0.671^{* *}$ & -0.074 & -0.098 \\
& $\mathrm{r}_{\mathrm{p}}$ & & & & & $0.511^{* *}$ & -0.071 & -0.091 \\
1000 seed weight (g) & $\mathrm{r}_{\mathrm{g}}$ & & & & & & $0.284^{* *}$ & $0.376^{* *}$ \\
& $\mathrm{r}_{\mathrm{p}}$ & & & & & & $0.232^{*}$ & $0.297^{* *}$ \\
Harvest index (\%) & $\mathrm{r}_{\mathrm{g}}$ & $\mathrm{r}_{\mathrm{p}}$ & & & & & & $0.245^{*}$ \\
& & & & & & & & $0.236^{*}$ \\
\hline
\end{tabular}

$*=$ significant at $5 \%$ level of probability

$* *=$ significant at $1 \%$ level of probability 
The results showed that yield was significantly genotypic and phenotypic correlated with plant height, raceme length, 1000 seed weight and harvest index. While, it showed significant negative genotypic and phenotypic correlatated with siliqua per raceme and siliqua length. Plant height showed significant positive genotypic correlation with raceme length. iliqua per raceme and harvest index. Plant height at maturity also showed significant negative correlation with siliqua length, seeds per siliqua and seed weight. Raceme length was found highly significant positive correlated with siliqua per raceme, yield per plant and also found significant negative correlation with seeds per siliqua 1000 seed weight .The similar trend of associations was reported by Chowdhury et al. (2007)._Number of siliqua per raceme, number of seeds per siliqua and 1000 seed weight had significant positive correlation with yield per plant.1000 seed weight per plant had highly significant correlation with harvest index and yield per plant. According to Kumer and Kakroo (2009), 1000 seed weight showed positive correlation with seed yield. Significant positive phenotypic and genotypic relationships were found in number of siliqua per raceme, 1000 seed weight and yield per plant. The result indicates that genotypes with higher number of siliqua per raceme, 1000 seed weight would produced more yield per plant, whereas significant correlation was found between yields per plant and these traits.

\section{Path Coefficient analysis}

Path analysis at genotypic level was done to see the direct and indirect effects of yield contributing characters on seed yield. The analysis revealed that plant height at maturity had the highest positive direct effect on seed yield followed by number of siliqua per raceme and number of seed per siliqua. Genotypic Path Coefficient analysis, direct and indirect effects of different yield and yield contributing characters in rapeseed are presented in Table 3.

Table 3. Direct effect (Bold and underline) and indirect effect of different yield contributing characters on yield per plant in rapeseed

\begin{tabular}{l|c|c|c|c|c|c|c|c}
\hline \multicolumn{1}{c|}{ Characters } & $\begin{array}{c}\text { Plant } \\
\text { height } \\
\text { (m) }\end{array}$ & $\begin{array}{c}\text { Raceme } \\
\text { length }\end{array}$ & $\begin{array}{l}\text { Siliqua/ } \\
\text { raceme }\end{array}$ & $\begin{array}{c}\text { Siliqua } \\
\text { length }\end{array}$ & $\begin{array}{c}\text { Seed/ } \\
\text { siliqua }\end{array}$ & $\begin{array}{c}\mathbf{1 0 0 0} \\
\text { seed wt }\end{array}$ & $\begin{array}{l}\text { Harves } \\
\text { t index }\end{array}$ & $\begin{array}{c}\text { Yield/ } \\
\text { plant }\end{array}$ \\
\hline Plant height $(\mathrm{m})$ & $\underline{\mathbf{0 . 9 3 5}}$ & 0.469 & 0.165 & 0.021 & -0.267 & -0.0562 & -0.922 & $0.484^{* *}$ \\
Raceme length & 0.929 & $\underline{\mathbf{0 . 4 9 3}}$ & 0.201 & -0.138 & -0.203 & -0.966 & -0.210 & $0.465^{* *}$ \\
Siliqua/raceme & 0.909 & 0.486 & $\underline{\mathbf{0 . 2 0 4}}$ & 0.022 & -0.388 & -0.794 & -0.942 & $-0.317^{* *}$ \\
Siliqua length & -0.183 & 0.437 & -0.029 & $\mathbf{- 0 . 1 5 6}$ & 0.356 & -0.901 & 0.269 & $-0.307^{* *}$ \\
Seed/siliqua & -0.809 & -0.224 & -0.177 & -0.125 & $\underline{\mathbf{0 . 4 4 7}}$ & 0.686 & 0.104 & 0.098 \\
1000 seed wt & -0.0704 & -0.466 & -0.158 & 0.153 & 0.299 & $\underline{\mathbf{0 . 8 0 2}}$ & -0.399 & $0.376^{* *}$ \\
Harvest index & 0.915 & 0.0735 & 0.136 & 0.0298 & -0.033 & 0.290 & $\underline{\mathbf{- 0 . 9 4 1}}$ & $0.245^{*}$ \\
\hline
\end{tabular}

\section{Bold and underline figures indicate the direct effect}

\section{Residual effect: 0.135}

Number of siliqua per raceme showed positive direct effect on yield per plant, The positive indirect effects of number of seeds per siliqua to seed yield were found via raceme length, plant height, siliqua length. It showed negative indirect effect on yield, seeds per siliqua, 1000 seed weight. Average siliqua length showed direct negative effect on yield and a high positive indirect effect via raceme length, seeds per siliqua, harvest index and negative indirect effects via plant height, siliqua per raceme, 1000 seed weight and yield per. Average number of seeds per siliqua showed a strong positive direct effect 
on seed yield. Its indirect positive effects on yield were contributed via 1000 seed weight, harvest index. Average 1000 seed weight showed positive direct effect on seed yield. Positive indirect effect showed via plant height, raceme length, siliqua length, 1000 seed weight and yield per plant. It showed negative indirect effect on yield via seeds per siliqua. Both the correlations and path analysis that the characters number of siliqua per raceme, seeds per siliqua appeared to be the first order yield component and ought to be given top priority in selection due to, strong association and direct effect on high magnitude on yield per plant.

\section{CONCLUSION}

The experiment was not only done for variability and association identification rather effectively finds out the selection criteria for the promotion of the noble genotypes from the experimented genotype fellows by evaluating the additive gene action governed characters. Correlation and path coefficients analysis can furnish a basis in determining the relative contribution of each character to seed yield. Hence, it can be concluded that number of siliqua per raceme showed high heritability along with high genetic advance and strong positive association along with high direct effect on seed yield. Therefore, selection of these characters would be more effective for the improvement of rapeseed.

\section{ACKNOWLEDGEMENTS}

I express our sincere thanks to Professor Dr. A.K.M. Shamsuddin, Associate Professor Dr. Ujjal Kumar Nath, Department of Genetics and Plant Breeding, Bangladesh Agricultural University, Mymensingh who supervised and co-supervised our research works.

\section{REFERENCES}

Akanksha, Singh P. K, O. P. Verma and K. Kumar. 2017. Genetic analysis for seed yield and its related attributes in Yellow Sarson (Brassica rapa var. Yellow Sarson). Journal of Oilseed Brassica, 8(1): 43-51

Ali, N., F. Javidfar; J. Y. Elmira and M. Y. Mirza. 2003. Relationship among yield components and selection criteria for yield improvement in winter Rapeseed (Brassica napus L.). Pakistan J. Bot. 35(2): 167-174.

Anonymous, 2015. Agricultural statistics at a glance. Governmentof India Ministry of Agriculture \& Farmers welfare Department of Agriculture, Cooperation and farmers welfare Directorate of Economics and Statistics, pp 120-122.

Burton, G.W. 1952. Quantitative inheritance in grass pea. Proc. $6^{\text {th }}$ Grassl. Cong. 1: 277283.

Burton, G. W. and E. H. Devane. 1953. Estimation of heritability in tall festca (Festuca arundinacea) from replicated clonal materials. Agronomy Journal, 45: 478-481

Chowdhury, N., F. Javidfar; J. Y. Elmira and M. Y. Mirza. 2007. Relationship among yield components and selection criteria for yield improvement in winter rapeseed (Brassica napus L.). Oilseed Research Program, National Agricultural Research Centre, Islamabad, Pakistan. 35(2): 167-17.

Dabholkar, A. R. 1992. Elements of Biometrical Genetics. Concept Publishing, New Delhi, India.

Dewey and Lu. 1959. Genetic variability and correlation in Indian rapeseed. Indian J. Agril. Sci. of North East India. 11(2): 262-264.

Dewey, D. R. and K. H. Lu. 1995. A correlation and path coefficient analysis of components of crested wheat grass seed production. Agron. J. 51: 515-518. 
Falconer, D. S. 1981. Introduction to quantitative genetics. 2nd ed., Longman, New York, USA.

Hasan M., F. Seyis, A. G. Badani, J. Pons-Kühnemann, W. Friedt, W. Luhs and R.J. Snowdon. 2006. Analysis of genetic diversity in the Brassica napus L. gene pool using SSR markers. Genet. Resour. Crop. Evol. 53: 793-802.

Johnson, K. F. and R. E. Comstoc. 1955. Genotypic and phenotypic correlation in rapeseed and implications in selection. Agron. J. 47(10): 477-483.

Khan, F. A., A. Sajid, S. Amir, S. Asif and A. Ghulam. 2006. Correlation analysis of some quantitative characters in Brassica napus L. Department of Plant Breeding and Genetics, University of Agriculture, Faisalabad, Pakistan. 44(1): 7-14.

Marjanovic-Jeromela, A., R. Marinkovi, A. Miji, Z. Zduni, S. Ivanovska and M. Jankulovsk. 2007. Correlation and path analysis of quantitative traits in winter rapeseed (Brassica napus L.). Agric. Consp. Sci. 73(1): 13-18.

Miller, S., H. L. Singh, Satyendra and R. K. Dixit. 1958. Studies on genetic variability, heritability, genetic advance and correlation in Indian rapeseed (Brassica napus (L.) Czern and Coss). Department of Genetics and Plant Breeding, Chandra Shekhar Azad University of Agriculture and Technology, Kanpur - 208002 (U. P.), Plant-Archives. 4(2): 291-294.

Sabaghnia, N., H. Dehghani, B. Alizadeh and M. Mohghaddam. 2010. Interrelationships between seed yield and 20 related traits of 49 canola genotypes in non-stressed and water stressed environments. Spanish J. Agril. Res. 8: 356-370.

Singh, R. K.; Chaudhary, B. D. Biometrical methods in quantitative genetic analysis. 1979 pp.x +304 pp. ref.82

Verma, Shubham, V. V. Singh, M. L. Meena, S. S. Rathore, Ram Bhagirath, Singh Subaran, Garg Pankaj, Singh B. R, Gurjar Neeraj, Ambawat Supriya, Singh Dhiraj. 2016. Genetic analysi of morphological and physiological traits in Indian mustard (Brassica juncea L.). SABRAO J. Breed. Genet. 48: 391-401 